\title{
Transsphenoidal surgery for Cushing's disease: a review of success rates, remission predictors, management of failed surgery, and Nelson's Syndrome
}

\author{
DANIEL F. Kelly, M.D. \\ Neuro-Endocrine Tumor Center, John Wayne Cancer Institute at Saint John's Health Center, \\ Santa Monica, California
}

\begin{abstract}
$\checkmark$ Cushing's disease is a serious endocrinopathy that, if left untreated, is associated with significant morbidity and mortality rates. After diagnostic confirmation of Cushing's disease has been made, transsphenoidal adenomectomy is the treatment of choice. When a transsphenoidal adenomectomy is performed at experienced transsphenoidal surgery centers, long-term remission rates average $80 \%$ overall, surgical morbidity is low, and the mortality rate is typically less than $1 \%$. In patients with well-defined noninvasive microadenomas, the long-term remission rate averages $90 \%$. For patients in whom primary surgery fails, treatment options such as bilateral adrenalectomy, stereotactic radiotherapy or radiosurgery, total hypophysectomy, or adrenolytic medical therapy need to be carefully considered, ideally in a multidisciplinary setting. The management of Nelson's Syndrome often requires both transsphenoidal surgery and radiotherapy to gain disease control. (DOI: 10.3171/FOC-07/09/E5)
\end{abstract}

\section{KEY WordS • adrenocorticotropic hormone • cortisol • Cushing's disease • Nelson's Syndrome • remission • transsphenoidal surgery}

$\mathrm{E}$ NDOGENOUS Cushing's syndrome is caused by an ACTH-secreting pituitary adenoma (Cushing's disease) in approximately $70 \%$ of cases. ${ }^{1,6,53,54}$ Cushing's disease is a serious endocrinopathy that, if untreated, greatly increases morbidity and carries a four-fold increased risk of mortality, largely related to associated cardiovascular complications and abnormal glucose metabolism. ${ }^{22,26,40,47,58}$ In addition to hypertension and diabetes mellitus, other problems resulting from excess cortisol include hyperlipidemia, metabolic syndrome, coagulopathy, osteoporosis, depression, anxiety, and cognitive impairment, all of which may further debilitate patients. ${ }^{1,54}$ Given the multiple deleterious effects of Cushing's disease, treatment to achieve normal cortisol levels is indicated for all patients. Effective treatment decreases morbidity (such as hypertension and diabetes mellitus) and mortality and results in age- and sex-adjusted survival rates similar to those of the general population..$^{25,26,45,58,71}$ Once the diagnosis of Cushing's disease is confirmed by a thorough endocrinological evaluation, transsphenoidal adenomectomy is considered the treatment of choice. In this review article, the success rates of first-time transsphenoidal surgery, repeat

Abbreviations used in this paper: $\mathrm{ACTH}=$ adrenocorticotropic hormone; $\mathrm{MR}=$ magnetic resonance. surgery, and transsphenoidal surgery for Nelson's Syndrome are discussed.

\section{Success Rate of Transsphenoidal Surgery for Cushing's Disease}

\section{The Early Years}

For almost three decades, transsphenoidal adenomectomy has been shown to offer patients the best chance for a sustained remission of Cushing's disease. Adenomectomy for Cushing's disease was first performed by Hardy in the early $1960 \mathrm{~s}^{2,3,27,28}$ In the 1970s, other groups including Salassa and Laws ${ }^{63}$ and Tyrrell and Wilson ${ }^{72}$ also began to adopt this approach for Cushing's disease with similar encouraging results. In these three reports of transsphenoidal microsurgery for Cushing's disease in a total of 63 patients, the clinical remission rate ranged from 68 to $89 \%$, with no deaths..$^{28,63,72}$ During the same period, use of hypophysectomy as an effective treatment for patients with Cushing's disease was reported by Lüdecke et al. in $1976^{43}$ and Carmalt and associates in $1977^{11}$ with remission rates of 50 and $85 \%$, respectively. In subsequent years, there have been numerous reports describing outcomes after transsphenoidal surgery for Cushing's disease performed 
using the sublabial, transseptal endonasal, and direct endonasal routes with the operating microscope. More recently, the purely endonasal endoscopic approach ${ }^{52}$ and the microscopic approach with endoscopic assistance have been employed.

\section{Contemporary Transsphenoidal Microsurgery for Cushing's Disease}

In 18 retrospective reports published since 1995 involving more than 3000 patients, all with a minimum of 40 patients and a minimum 6-month follow-up, the remission rate ranged from 69 to $98 \%$ (simple [unweighted] average $79 \%$ ), the recurrence rate from 3 to $17 \%$ (simple average $10 \%$ ), and the acute surgical mortality rate from 0 to $1.9 \%$ (Table 1). Of the series' conducted at single centers, the smallest study included 41 patients $^{62}$ and the largest included 310 patients. ${ }^{37}$ Of the studies addressing transsphenoidal surgery as the primary treatment, long-term remission rates ranged from 69 to $98 \%$ (simple average 83\%), recurrence rates from 5 to $11.5 \%$ (simple average $8 \%$ ), and mortality rates from 0 to $1.9 \% .^{20,24,26,37,61,62,67,70,76}$ The best long-term remission rates, ranging from 86 to $98 \%$, are found in patients with noninvasive microadenomas treated with primary transsphenoidal tumor removal. ${ }^{4,10,16,20,24,26,61,67,70}$ In contrast, lower remission rates are noted in patients with macroadenomas (range $31-83 \%$ ) or invasive adenomas (range 22-65\%)., $4,10,26,61,67,70$

Long-term postoperative surveillance of successfully treated patients with Cushing's disease is important because late recurrences occur; the median interval of disease recurrence ranges from 2.3 to 7.2 years after surgery and can be as late as 10 years after surgery. ${ }^{15,26,56,70}$ Similar rates of remission (range 56-98\%) have been noted for pediatric patients with Cushing's disease treated using transsphenoidal surgery. $918,19,33,39,46,55,64$ The recurrence rate may be somewhat higher, however, as noted in several pediatric series. . $^{18,38,39,55}$

\section{Selective Adenomectomy Compared with Hypophysectomy}

In the patient series cited earlier, the initial goal of surgery was generally to remove an adenoma selectively. If no adenoma was found, in most instances a partial or total hypophysectomy was performed. In these patient series, the type of operation performed (selective adenomectomy and partial or total hypophysectomy) did not appear to have a significant effect on the long-term remission rate. . $^{5,15,26,61}$ With increased removal of pituitary gland tissue, however, there is an increased rate of anterior and posterior pituitary failure. ${ }^{26,61}$ In two earlier patient series in which total hypophysectomy was the goal, new pituitary failure was seen in 79 to $95 \%$ of patients; however, using hemihypophysectomy, the rate of new failure was considerably lower., ${ }^{75,71}$

\section{New Pituitary Failure and Other Complications}

The overall rate of anterior pituitary failure in the 19 patient series cited in Table 1 and published since 1995 ranged from 2 to $41 \%$, but was typically less than $20 \%$ in most series; the incidence rate of permanent diabetes insipidus ranged from 3 to $9 \%$. This relatively high rate of hypopituitarism associated with adenomectomy appears to be directly related to the use of partial or complete hy- pophysectomy required in a substantial minority of patients to maximize the chance of remission. In one recent report of using a purely endoscopic approach in 35 consecutive patients with Cushing's disease, the overall remission rate was $83 \%$; however, the rate of new hypopituitarism, excluding isolated hypoadrenalism, was relatively high $(48 \%)^{52}$ Other surgical complications in most transsphenoidal series are generally uncommon, including: cerebrospinal fluid leaks $(0-8 \%)$, meningitis $(0-3 \%)$, new neurological deficits $(0-2 \%)$, postoperative hematomas $(0-6 \%$, generally $<1 \%)$, thromboembolic events $(0-4 \%)$, and wound or nasoseptal complications $(0-4 \%))^{15,20,26,65}$

\section{Early Reoperations for Persistent Cushing's Disease}

After an unsuccessful initial operation for Cushing's disease, early reoperation within 60 days after the original surgery can result in a sustained remission in 38 to $67 \%$ of patients. ${ }^{14,37,42,60}$ If obvious adenoma was left within the gland at the first operation, this tumor may be visible on postoperative MR imaging; however, in most instances there is little utility in repeating MR imaging in these patients. In contrast, petrosal sinus sampling using corticotropin-releasing hormone stimulation appears useful for confirming the need for repeated surgery, if not performed prior to the initial procedure. ${ }^{42}$ In most reports, patients underwent a hemihypophysectomy or total hypophysectomy after a more limited initial operation. Second operations, however, are associated with a higher rate of postoperative cerebrospinal fluid leaks and hypopituitarism. 14,37,42,60 Thus, it is reasonable to consider early reoperation only if residual adenoma is thought to reside in the gland and not within the cavernous sinus or skull base bone, which are factors that reduce the likelihood of achieving a remission rate to less than $50 \%$.

\section{Predicting Long-Term Remission after Transsphenoidal Surgery}

Several methods of assessing early remission have been used to predict long-term remission from Cushing's disease. Provocative tests include the overnight low-dose dexamethasone suppression test and the corticotropinreleasing hormone stimulation test. Nonprovocative tests include assessment of serum cortisol and ACTH levels and 24-hour urinary free cortisol concentrations within the early postoperative period. Recent studies indicate that both provocative and nonprovocative tests have a similar high rate of predicting remission in Cushing's disease. For example, Chen and colleagues ${ }^{15}$ showed that a morning cortisol level on postoperative Day 3 of $3 \mu \mathrm{g} / \mathrm{dl}$ or less after an overnight $1 \mathrm{mg}$ dexamethasone suppression test was predictive of sustained remission in $93 \%$ of patients. In the subset of 116 patients with microadenomas, the remission rate at 5 years after surgery was $96.5 \%$.

In contrast, in three recent reports in which glucocorticoids were withheld in the early postoperative period until hypocortisolemia was evident, subnormal but not necessarily undetectable serum cortisol levels within 72 hours of surgery were highly predictive of sustained remission..$^{20,62,68}$ In the report by Simmons and associates ${ }^{68}$ cortisol levels were measured every 6 hours for as long as 3 days after surgery, with a "low serum cortisol" cutoff value of 10 $\mu \mathrm{g} / \mathrm{dl}(275.9 \mathrm{nmol} / \mathrm{L}) ; 21$ patients $(78 \%)$ met this cutoff cri- 
TABLE 1

Summary of studies of contemporary transsphenoidal microsurgery for Cushing's disease*

\begin{tabular}{|c|c|c|c|c|c|c|c|c|}
\hline Author \& Year & $\begin{array}{c}\text { No. of } \\
\text { Pts (\% F) }\end{array}$ & $\begin{array}{c}\text { Evidence } \\
\text { Class } \dagger\end{array}$ & $\begin{array}{l}\text { Mean Age } \\
\text { (range in yrs) }\end{array}$ & $\mathrm{FU}(\mathrm{yrs})$ & $\begin{array}{c}\text { Remission } \\
(\%)\end{array}$ & $\begin{array}{c}- \\
\text { Recur }(\%)\end{array}$ & $\begin{array}{c}\text { Time to } \\
\text { Recur (yrs) }\end{array}$ & $\begin{array}{l}\text { Mortality } \\
(\%)\end{array}$ \\
\hline $\begin{array}{l}\text { Bochicchio } \\
\text { et al., 1995 } \ddagger \S\end{array}$ & $668(77)$ & III & $38(8-84)$ & 2 (mean) & 76 , prim \& sec & 13 & $0.5-8.7$ & 1.9 \\
\hline Sonino et al., $1996 \S$ & $103(77)$ & II & $37(11-71)$ & 7 (med) & 77 , all prim & 19,26 & 5,10 & NA \\
\hline Blevins et al., 1998 & 106 (NA) & III & 38 & 5.2 (mean) & $\begin{array}{l}\text { 91, micro } \\
67, \text { macro } \\
\text { (prim vs sec NA) }\end{array}$ & $\begin{array}{l}12 \\
36\end{array}$ & NA & NA \\
\hline Invitti et al., 1999 & $236(83)$ & III & $36(11-72)$ & 2.3 & 69 & 17 & NA & NA \\
\hline $\begin{array}{l}\text { Swearingen et al., } \\
1999 \$ \S\end{array}$ & $161(80)$ & III & $38(8-76)$ & 8 (med) & $\begin{array}{l}85, \text { prim \& sec } \\
90, \text { prim micro } \\
65, \text { prim macro }\end{array}$ & 7 & $\begin{array}{l}4 \text { (med) } \\
1-11 \text { (range) }\end{array}$ & 0 \\
\hline Cavagnini et al., 2001 & $300(83)$ & III & NA & NA & 70 (prim vs sec NA) & 15 & NA & NA \\
\hline Chee et al., $2001 \div \S$ & $61(74)$ & III & $37(12-69)$ & 7.3 (med) & 79, prim \& sec & 14.6 & $1.8-13$ (range) & 0 \\
\hline Rees et al., $2002 \S$ & $54(78)$ & III & $41(14-73)$ & 6 (med) & $\begin{array}{l}\text { 77, all prim } \\
86 \text {, intrasellar } \\
40 \text {, extrasellar }\end{array}$ & 5 & $1.1-3$ (range) & 1.9 \\
\hline Yap et al., $2002 \S$ & $97(80)$ & III & $39(14-82)$ & 7.7 (mean) & 69 , all prim & 11.5 & $0.7-6$ (range) & 1 \\
\hline Chen et al., $2003 \S$ & $174(68)$ & III & $8-57$ & $\geq 5(\min )$ & 74 (prim vs sec NA) & 7 & 2.3 (med) & 0 \\
\hline Flitsch et al., 2003 & $147(76)$ & III & 35 & NA & 98 , all prim & 5.5 & NA & 0 \\
\hline Pereira et al., $2003 \ddagger \S$ & $78(80)$ & III & $37(12-81)$ & 7 (med) & 72, prim \& sec & 9 & $\begin{array}{l}7.2 \text { (med) } \\
2-20 \text { (range) }\end{array}$ & 1.2 \\
\hline Hammer et al., 2004 & $289(83)$ & III & $37(18-72)$ & 11.1 (med) & $\begin{array}{l}82, \text { all prim } \\
86, \text { micro } \\
83 \text {, macro } \\
65 \text {, invasive }\end{array}$ & $\begin{array}{r}9 \text { (of } \\
150 \\
\text { pts) }\end{array}$ & $1.7(1 \mathrm{pt})$ & 1 \\
\hline Rollin, et al., $2004 \ddagger \S$ & $41(73)$ & II & $38(12-62)$ & 4.8 (mean) & 87.5 , all prim & 5 & NA & NA \\
\hline Esposito et al., 2006 & $40(93)$ & III & $39(21-70)$ & 2.7 (mean) & $\begin{array}{l}\text { 79.5, all } \\
93 \text {, prim } \\
45, \text { sec }\end{array}$ & 3 & $1.7(1 \mathrm{pt})$ & $1 \mathrm{pt}$ \\
\hline
\end{tabular}

$* \mathrm{FU}=$ follow-up macro = macroadenoma med $=$ median $;$ micro $=$ microadenoma $; \mathrm{NA}=$ not available $; \mathrm{pt}=$ patient $;$ prim $=$ primary; recur $=$ recurrent; $\mathrm{sec}=$ secondary.

$\dagger$ Evidence Class II are prospective nonrandomized case series; Evidence Class III are retrospective case series.

† In six series including patients treated with surgery both as primary and secondary therapy (repeat transsphenoidal surgery), the percentage of patients undergoing a second procedure ranged from 4 to $26 \%$.

$\S$ In 10 series, pediatric patients were included.

॥ Refers to reference 37.

terion and $100 \%$ of these 21 patients were in remission after a mean follow-up period of 27 months ${ }^{68}$ In the report by Rollin and coworkers, ${ }^{62}$ cortisol levels were obtained at 6,12 , and 24 hours postoperatively; of 21 patients $(81 \%)$ in remission at a median follow-up of 34 months, serum cortisol levels 24 hours after surgery averaged $4.7 \pm 6.8 \mu \mathrm{g} / \mathrm{dl}$ (range $0.5-30 \mu \mathrm{g} / \mathrm{dl}$ ). In the recent patient series reported by Esposito et al. ${ }^{20}$ in the 32 patients achieving early remission, the average morning cortisol nadir was $2.05 \pm 1.2$ $\mu \mathrm{g} / \mathrm{dl}$. In this study, a morning cortisol level of $5 \mu \mathrm{g} / \mathrm{dl}$ or less on postoperative Day 1 or 2 was predictive of sustained remission in $97 \%$ of patients.

Regarding the absolute cortisol criterion establishing early remission, it appears that use of a more traditional value of nondetectable serum cortisol $(<50 \mathrm{nmol} / \mathrm{L}$, or $<$ $1.8 \mu \mathrm{g} / \mathrm{dl}$ ) is excessively stringent given that more than $50 \%$ of patients who achieved remission in these three studies had a nadir cortisol level above this threshold with- in 3 days of surgery. ${ }^{20,62,68}$ It should be noted that these studies also show that up to $4.5 \%$ of patients who achieve remission will not be identified within the first 72 postoperative hours and instead will have a delayed decrease in their cortisol values. ${ }^{20,62,68}$ Regarding the predictive value of early ACTH levels, only one-third of the patients in our recent series had a subnormal ACTH level during this early postoperative period, indicating that absolute ACTH level is a poor predictor of sustained remission. ${ }^{20}$

There are several advantages of using early postoperative serum cortisol levels to assess early remission. First, this method requires no provocative testing and it gives an early and relatively reliable answer as to whether the patient is in remission, typically within 48 hours of surgery and prior to patient discharge home. Second, although patients with a successful operation without glucocorticoid replacement often develop symptoms of hypocortisolemia, manifestations of an adrenal crisis have not been reported. 
Finally, this paradigm allows early identification of patients who initially had an unsuccessful first surgery, who may be candidates for a second operation within days of the first operation..$^{20,42}$

\section{Management of Cushing's Disease after Failed Transsphenoidal Surgery}

After a failed transsphenoidal surgery for Cushing's disease, treatment options include: 1) repeated transsphenoidal surgery; 2) bilateral adrenalectomies; 3 ) radiation therapy; 4) pharmacological therapy; or 5) a combination of these measures. The treatment options of bilateral adrenalectomy and radiation therapy are discussed in detail.

\section{Bilateral Adrenalectomy}

Bilateral adrenalectomy for the treatment of Cushing's disease became popular in the 1950s. As perioperative management and steroid replacement became widely available, patient mortality and immediate morbidity rates as a result of the operation were greatly reduced. Primary or secondary bilateral adrenalectomy for Cushing's disease has a very high success rate in reversing hypercortisolism, ranging from 88 to $100 \%$. Over time, however, there is a significant risk of patients' developing Nelson's Syndrome. In patient series published since 1983 with adequate follow-up, the rate of Nelson's Syndrome ranged from 15 to $46 \%$. $8,23,29,32,34,48,50,57,69$ Only one study that addressed the role of radiation therapy demonstrated that prior radiation therapy reduced the risk and delayed the onset of developing Nelson's Syndrome; however, this potential beneficial effect of radiotherapy remains understudied. ${ }^{50}$ The average interval between a bilateral adrenalectomy and the development of Nelson's Syndrome is approximately 5 to 10 years, but may be as short as 6 months and as long as 24 years. ${ }^{32,34,50}$ The long-term risk of developing Nelson's Syndrome after a bilateral adrenalectomy is at least 25 to $30 \%$, and there is a significant risk of major pituitary tumor enlargement, particularly in those patients with visible adenomas on MR imaging or computed tomography. Therefore, use of bilateral adrenalectomy as a first-line therapy is generally contraindicated. ${ }^{69}$ Furthermore, as described later, the ACTH-secreting adenomas associated with Nelson's Syndrome tend to be invasive and relatively aggressive in their growth pattern, further complicating their management.

\section{Radiation Therapy}

Although radiation therapy was widely used as a firstline therapy for Cushing's disease from the 1940s to the early 1980s, it is typically used now as a secondary treatment after failed transsphenoidal surgery. In the largest series of patients undergoing secondary external radiation therapy after failed transsphenoidal surgery, remission rates ranged from 53 to $83 \%$, and recurrence rates from 0 to $17 \% \%^{21,31,73}$ The study results of Sonino and colleagues ${ }^{69}$ indicate that prior unsuccessful surgery is a predictor of longterm success for external radiation therapy. In their study, all nine patients $(100 \%)$ with prior transsphenoidal surgery had sustained remission after undergoing external radiation therapy, whereas only seven (50\%) of 14 patients who received radiation as a primary treatment had sustained remission.

In the two largest series of patients who underwent secondary radiosurgery using the Gamma knife (single fraction therapy), remission rates were $63^{66}$ and $73 \% .{ }^{59}$ The recurrence rate was $11 \%$ in the study of Sheehan and coworkers, ${ }^{66}$ resulting in a control rate of $52 \%$. A more recent report of 40 patients treated using Gamma knife radiosurgery as either a primary (in 11 patients) or secondary therapy (in 29 patients) demonstrated a $42 \%$ remission rate after a mean follow-up of 22 months. ${ }^{12}$ Both external beam and stereotactic radiation therapy appear to result in similar rates of radiation-induced pituitary failure, ranging from 16 to $57 \%$; the rates of hypopituitarism appear to increase with longer follow-up periods. . $^{17,21,41,49,57,69}$

Overall, these studies indicate that radiation therapy is an effective secondary treatment for patients with Cushing's disease who have undergone unsuccessful surgery. Currently, however, given the relatively higher long-term remission rates in transsphenoidal adenomectomy, radiation therapy should be considered a first-line therapy only in cases of uncontrolled Cushing's disease with severe medical complications. In such patients who are medically unstable and in whom induction of anesthesia poses high risks, radiotherapy is a reasonable treatment option when performed in conjunction with adrenolytic medical therapy to achieve a relatively rapid lowering of cortisol levels.

\section{Treatment of Nelson's Syndrome}

As previously noted, after a patient with Cushing's disease undergoes bilateral adrenalectomy, the risk of developing Nelson's Syndrome is relatively high, ranging from 15 to $46 \% .8,23,29,32,34,48,50,57,69$ The neurosurgical management of Nelson's Syndrome is challenging, due to the aggressive and often invasive nature of these ACTH-secreting adenomas. In five patient series published from 1982 to 2002, surgery was effective in improving or restoring vision and reducing the degree of hyperpigmentation in the great majority of patients. The ACTH levels normalized in fewer than $50 \%$ of patients, however, and additional radiation therapy was required in 20 to $30 \%$ of such patients to help control tumor growth. $35,36,44,74,75$

\section{References}

1. Arnaldi G, Angeli A, Atkinson AB, Bertagna X, Cavagnini F, Chrousos GP, et al: Diagnosis and complications of Cushing's syndrome: a consensus statement. J Clin Endocrinol Metab 88:5593-5602, 2003

2. Bigos ST, Robert F, Pelletier G, Hardy J: Cure of Cushing's disease by transsphenoidal removal of a microadenoma from a pituitary gland despite a radiographically normal sella turcica. J Clin Endocrinol Metab 45:1251-1260, 1977

3. Bigos ST, Somma M, Rasio E, Eastman RC, Lanthier A, Johnston $\mathrm{HH}$, et al: Cushing's disease: management by transsphenoidal pituitary microsurgery. J Clin Endocrinol Metab 50:348-354, 1980

4. Blevins LS Jr, Christy JH, Khajavi M, Tindall GT: Outcomes of therapy for Cushing's disease due to adrenocorticotropin-secreting pituitary macroadenomas. J Clin Endocrinol Metab 83: 63-67, 1998

5. Bochicchio D, Losa M, Buchfelder M: Factors influencing the immediate and late outcome of Cushing's disease treated by transsphenoidal surgery: a retrospective study by the European 
Cushing's Disease Survey Group. J Clin Endocrinol Metab 80: 3114-3120, 1995

6. Boscaro M, Barzon L, Fallo F, Sonino N: Cushing's syndrome. Lancet 357:783-791, 2001

7. Brand IR, Dalton GA, Fletcher RF: Long-term follow up of transsphenoidal hypophysectomy for Cushing's disease. J R Soc Med 78:291-293, 1985

8. Brunicardi FC, Rosman PM, Lesser KL, Andersen DK: Current status of adrenalectomy for Cushing's disease. Surgery 98: 1127-1134, 1985

9. Buchfelder M, Fahlbusch R: Neurosurgical treatment of Cushing's disease in children and adolescents. Acta Neurochir (Wien) Suppl 35:101-105, 1985

10. Cannavo S, Almoto B, Dall'Asta C, Corsello S, Lovicu RM, De Menis E, et al: Long-term results of treatment in patients with ACTH-secreting pituitary macroadenomas. Eur J Endocrinol 149:195-200, 2003

11. Carmalt MH, Dalton GA, Fletcher RF, Smith WT: The treatment of Cushing's disease by trans-sphenoidal hypophysectomy. Q J Med 46:119-134, 1977

12. Castinetti F, Nagai M, Dufour H, Kuhn JM, Morange I, Jaquet P, et al: Gamma knife radiosurgery is a successful adjunctive treatment in Cushing's disease. Eur J Endocrinol 156:91-98, 2007

13. Cavagnini F, Pecori Giraldi F: Epidemiology and follow-up of Cushing's disease. Ann Endocrinol (Paris) 62:168-172, 2001

14. Chee GH, Mathias DB, James RA, Kendall-Taylor P: Transsphenoidal pituitary surgery in Cushing's disease: can we predict outcome? Clin Endocrinol (Oxf) 54:617-626, 2001

15. Chen JC, Amar AP, Choi S, Singer P, Couldwell WT, Weiss MH: Transsphenoidal microsurgical treatment of Cushing disease: postoperative assessment of surgical efficacy by application of an overnight low-dose dexamethasone suppression test. J Neurosurg 98:967-973, 2003

16. Damiani D, Aguiar $\mathrm{CH}$, Crivellaro $\mathrm{CE}$, Galvão JA, Dichtchekenian V, Setian N: Pituitary macroadenoma and Cushing's disease in pediatric patients: patient report and review of the literature. J Pediatr Endocrinol Metab 11:665-669, 1998

17. Degerblad M, Rahn T, Bergstrand G, Thoren M: Long-term results of stereotactic radiosurgery to the pituitary gland in Cushing's disease. Acta Endocrinol (Copenh) 112:310-314, 1986

18. Devoe DJ, Miller WL, Conte FA, Kaplan SL, Grumbach MM, Rosenthal SM, et al: Long-term outcome in children and adolescents after transsphenoidal surgery for Cushing's disease. J Clin Endocrinol Metab 82:3196-3202, 1997

19. Dyer EH, Civit T, Visot A, Delalande O, Derome P: Transsphenoidal surgery for pituitary adenomas in children. Neurosurgery 34:207-212, 1994

20. Esposito F, Dusick JR, Cohan P, Moftakhar P, McArthur D, Wang $\mathrm{C}$, et al: Clinical review: early morning cortisol levels as a predictor of remission after transsphenoidal surgery for Cushing's disease. J Clin Endocrinol Metab 91:7-13, 2006

21. Estrada J, Boronat M, Mielgo M, Magallón R, Millan I, Díez S, et al: The long-term outcome of pituitary irradiation after unsuccessful transsphenoidal surgery in Cushing's disease. N Engl J Med 336:172-177, 1997

22. Etxabe J, Vazquez JA: Morbidity and mortality in Cushing's disease: an epidemiological approach. Clin Endocrinol (Oxf) 40: 479-484, 1994

23. Favia G, Boscaro M, Lumachi F, D'Amico DF: Role of bilateral adrenalectomy in Cushing's disease. World J Surg 18:462-466, 1994

24. Flitsch J, Knappe UJ, Ludecke DK: The use of postoperative ACTH levels as a marker for successful transsphenoidal microsurgery in Cushing's disease. Zentralbl Neurochir 64:6-11, 2003

25. Grabner P, Hauer-Jensen M, Jervell J, Flatmark A: Long-term results of treatment of Cushing's disease by adrenalectomy. Eur J Surg 157:461-464, 1991

26. Hammer GD, Tyrrell JB, Lamborn KR, Applebury CB, Hannegan
ET, Bell S, et al: Transsphenoidal microsurgery for Cushing's disease: initial outcome and long-term results. J Clin Endocrinol Metab 89:6348-6357, 2004

27. Hardy J: Presidential address: XVII Canadian Congress of Neurological Sciences. Cushing's disease: 50 years later. Can J Neurol Sci 9:375-380, 1982

28. Hardy J: The transsphenoidal surgical approach to the pituitary. Hosp Pract 14:81-89, 1979

29. Hardy JD, Moore DO, Langford HG: Cushing's disease today. Late follow-up of 17 adrenalectomy patients with emphasis on eight with adrenal autotransplants. Ann Surg 201:595-603, 1985

30. Hofmann BM, Fahlbusch R: Treatment of Cushing's disease: a retrospective clinical study of the latest 100 cases. Front Horm Res 34:158-184, 2006

31. Imaki T, Tsushima T, Hizuka N, Odagiri E, Murata Y, Suda T, et al: Postoperative plasma cortisol levels predict long-term outcome in patients with Cushing's disease and determine which patients should be treated with pituitary irradiation after surgery. Endocr J 48:53-62, 2001

32. Invitti C, Pecori Giraldi F, de Martin M, Cavagnini F: Diagnosis and management of Cushing's syndrome: results of an Italian multicentre study. Study Group of the Italian Society of Endocrinology on the Pathophysiology of the Hypothalamic-Pituitary-Adrenal Axis. J Clin Endocrinol Metab 84:440-448, 1999

33. Kanter AS, Diallo AO, Jane JA Jr, Sheehan JP, Asthagiri AR, Oskouian RJ, et al: Single-center experience with pediatric Cushing's disease. J Neurosurg 103 (5 Suppl):413-420, 2005

34. Kasperlik-Zaluska AA, Nielubowicz J, Wislawski J, Hartwig W, Zaluska J, Jeske W, et al: Nelson's syndrome: incidence and prognosis. Clin Endocrinol (Oxf) 19:693-698, 1983

35. Kelly PA, Samandouras G, Grossman AB, Afshar F, Besser GM, Jenkins PJ: Neurosurgical treatment of Nelson's syndrome. J Clin Endocrinol Metab 87:5465-5469, 2002

36. Kemink SA, Grotenhuis JA, De Vries J, Pieters GF, Hermus AR, Smals AG: Management of Nelson's syndrome: observations in fifteen patients. Clin Endocrinol (Oxf) 54:45-52, 2001

37. Knappe UJ, Lüdecke DK: Persistent and recurrent hypercortisolism after transsphenoidal surgery for Cushing's disease. Acta Neurochir Suppl 65:31-34, 1996

38. Knappe UJ, Lüdecke DK: Transnasal microsurgery in children and adolescents with Cushing's disease. Neurosurgery 39: 484-493, 1996

39. Leinung MC, Kane LA, Scheithauer BW, Carpenter PC, Laws ER Jr, Zimmerman D: Long term follow-up of transsphenoidal surgery for the treatment of Cushing's disease in childhood. J Clin Endocrinol Metab 80:2475-2479, 1995

40. Lindholm J, Juul S, Jørgensen JO, Astrup J, Bjerre P, Feldt-Rasmussen U, et al: Incidence and late prognosis of cushing's syndrome: a population-based study. J Clin Endocrinol Metab 86: 117-123, 2001

41. Littley MD, Shalet SM, Beardwell CG, Ahmed SR, Sutton ML: Long-term follow-up of low-dose external pituitary irradiation for Cushing's disease. Clin Endocrinol (Oxf) 33:445-455, 1990

42. Locatelli M, Vance ML, Laws ER: Clinical review: the strategy of immediate reoperation for transsphenoidal surgery for Cushing's disease. J Clin Endocrinol Metab 90:5478-5482, 2005

43. Lüdecke D, Kautzky R, Saeger W, Schrader D: Selective removal of hypersecreting pituitary adenomas? An analysis of endocrine function, operative and microscopical findings in 101 cases. Acta Neurochir (Wien) 35:27-42, 1976

44. Lüdecke DK, Breustedt HJ, Brämswig J, Köbberling J, Saeger W: Evaluation of surgically treated Nelson's syndrome. Acta Neurochir (Wien) 65:3-13, 1982

45. Lüdecke DK, Niedworok G: Results of microsurgery in Cushing's disease and effect on hypertension. Cardiology 72 (1 Suppl): 91-94, 1985 
46. Magiakou MA, Mastorakos G, Oldfield EH, Gomez MT, Doppman JL, Cutler GB Jr, et al: Cushing's syndrome in children and adolescents. Presentation, diagnosis, and therapy. N Engl J Med 331:629-636, 1994

47. Mancini T, Kola B, Mantero F, Boscaro M, Arnaldi G: High cardiovascular risk in patients with Cushing's syndrome according to 1999 WHO/ISH guidelines. Clin Endocrinol (Oxf) 61:768-777, 2004

48. McCance DR, Russell CF, Kennedy TL, Hadden DR, Kennedy L, Atkinson AB: Bilateral adrenalectomy: low mortality and morbidity in Cushing's disease. Clin Endocrinol (Oxf) 39:315-321, 1993

49. Murayama M, Yasuda K, Minamori Y, Mercado-Asis LB, Yamakita N, Miura K: Long term follow-up of Cushing's disease treated with reserpine and pituitary irradiation. J Clin Endocrinol Metab 75:935-942, 1992

50. Nagesser SK, van Seters AP, Kievit J, Hermans J, Krans HM, van de Velde CJ: Long-term results of total adrenalectomy for Cushing's disease. World J Surg 24:108-113, 2000

51. Nagesser SK, van Seters AP, Kievit J, Hermans J, van Dulken H, Krans HM, et al: Treatment of pituitary-dependent Cushing's syndrome: long-term results of unilateral adrenalectomy followed by external pituitary irradiation compared to transsphenoidal pituitary surgery. Clin Endocrinol (Oxf) 52:427-435, 2000

52. Netea-Maier RT, van Lindert EJ, den Heijer M, van der Eerden A, Pieters GF, Sweep CG, et al: Transsphenoidal pituitary surgery via the endoscopic technique: results in 35 consecutive patients with Cushing's disease. Eur J Endocrinol 154:675-684, 2006

53. Newell-Price J: Transsphenoidal surgery for Cushing's disease: defining cure and following outcome. Clin Endocrinol (Oxf) 56: 19-21, 2002

54. Orth DN: Cushing's syndrome. N Engl J Med 332:791-803, 1995

55. Partington MD, Davis DH, Laws ER Jr, Scheithauer BW: Pituitary adenomas in childhood and adolescence. Results of transsphenoidal surgery. J Neurosurg 80:209-216, 1994

56. Pereira AM, van Aken MO, van Dulken H, Schutte PJ, Biermasz NR, Smit JW, et al: Long-term predictive value of postsurgical cortisol concentrations for cure and risk of recurrence in Cushing's disease. J Clin Endocrinol Metab 88:5858-5864, 2003

57. Pereira MA, Halpern A, Salgado LR, Mendonça BB, Nerv M, Liberman B, et al: A study of patients with Nelson's syndrome. Clin Endocrinol (Oxf) 49:533-539, 1998

58. Pikkarainen L, Sane T, Reunanen A: The survival and well-being of patients treated for Cushing's syndrome. J Intern Med 245: 463-468, 1999

59. Pollock BE, Kondziolka D, Lunsford LD, Flickinger JC: Stereotactic radiosurgery for pituitary adenomas: imaging, visual and endocrine results. Acta Neurochir Suppl 62:33-38, 1994

60. Ram Z, Nieman LK, Cutler GB Jr, Chrousos GP, Doppman JL, Oldfield EH: Early repeat surgery for persistent Cushing's disease. J Neurosurg 80:37-45, 1994

61. Rees DA, Hanna FW, Davies JS, Mills RG, Vafidis J, Scanlon MF: Long-term follow-up results of transsphenoidal surgery for Cushing's disease in a single centre using strict criteria for remission. Clin Endocrinol (Oxf) 56:541-551, 2002

62. Rollin GA, Ferreira NP, Junges M, Gross JL, Czepielewski MA: Dynamics of serum cortisol levels after transsphenoidal surgery in a cohort of patients with Cushing's disease. J Clin Endocrinol Metab 89:1131-1139, 2004
63. Salassa RM, Laws ER Jr, Carpenter PC, Northcutt RC: Transsphenoidal removal of pituitary microadenoma in Cushing's disease. Mayo Clin Proc 53:24-28, 1978

64. Savage MO, Lienhardt A, Lebrethon MC, Johnston LB, Huebner A, Grossman AB, et al: Cushing's disease in childhood: presentation, investigation, treatment and long-term outcome. Horm Res 55 (Suppl 1):24-30, 2001

65. Semple PL, Laws ER Jr: Complications in a contemporary series of patients who underwent transsphenoidal surgery for Cushing's disease. J Neurosurg 91:175-179, 1999

66. Sheehan JM, Vance ML, Sheehan JP, Ellegala DB, Laws ER Jr: Radiosurgery for Cushing's disease after failed transsphenoidal surgery. J Neurosurg 93:738-742, 2000

67. Shimon I, Ram Z, Cohen ZR, Hadani M: Transsphenoidal surgery for Cushing's disease: endocrinological follow-up monitoring of 82 patients. Neurosurgery 51:57-62, 2002

68. Simmons NE, Alden TD, Thorner MO, Laws ER Jr: Serum cortisol response to transsphenoidal surgery for Cushing disease. J Neurosurg 95:1-8, 2001

69. Sonino N, Zielezny M, Fava GA, Fallo F, Boscaro M: Risk factors and long-term outcome in pituitary-dependent Cushing's disease. J Clin Endocrinol Metab 81:2647-2652, 1996

70. Swearingen B, Biller BM, Barker FG II, Katznelson L, Grinspoon S, Klibanski A, et al: Long-term mortality after transsphenoidal surgery for Cushing disease. Ann Intern Med 130:821-824, 1999

71. Thomas JP, Richards SH: Long term results of radical hypophysectomy for Cushing's disease. Clin Endocrinol (Oxf) 19: 629-636, 1983

72. Tyrrell JB, Brooks RM, Fitzgerald PA, Cofoid PB, Forsham PH, Wilson CB: Cushing's disease. Selective trans-sphenoidal resection of pituitary microadenomas. N Engl J Med 298:753-758, 1978

73. Vicente A, Estrada J, de la Cuerda C, Astigarraga B, Marazuela M, Blanco C, et al: Results of external pituitary irradiation after unsuccessful transsphenoidal surgery in Cushing's disease. Acta Endocrinol (Copenh) 125:470-474, 1991

74. Wislawski J, Kasperlik-Zaluska AA, Jeske W, Migdalska B, Janik $\mathrm{J}$, Zaluska $\mathrm{J}$, et al: Results of neurosurgical treatment by a transsphenoidal approach in 10 patients with Nelson's syndrome. J Neurosurg 62:68-71, 1985

75. Xing B, Ren Z, Su C, Wang R, Yang Y, Hu Y: Microsurgical treatment of Nelson's syndrome. Chin Med J (Engl) 115: 1150-1152, 2002

76. Yap LB, Turner HE, Adams CB, Wass JA: Undetectable postoperative cortisol does not always predict long-term remission in Cushing's disease: a single centre audit. Clin Endocrinol (Oxf) 56:25-31, 2002

Manuscript submitted May 17, 2007,

Accepted July 24, 2007.

Address correspondence to: Daniel F. Kelly, M.D., John Wayne Cancer Institute at Saint John's Health Center, 2200 Santa Monica Blvd, Santa Monica Boulevard, California 90404. email: kellyd @jwci.org. 